\title{
The Patterns of Venture Capital InVestment in
}

\section{EUROPE}

Fabio Bertoni
Massimo G. Colombo
Anita Quas*

\begin{abstract}
We study the investment patterns of different types of venture capital (VC) investors in Europe: independent VC, corporate VC, bank-affiliated VC and governmental VC. We rely on a unique dataset that covers 1,663 first VC investments made by 846 investors in 737 young high-tech entrepreneurial ventures in seven European countries. We compare the relative specialization indices of the different $\mathrm{VC}$ investor types across several dimensions that characterize investee companies: industry, age, size, stage of development, distance from the investor and country. Our findings indicate that VC investor types in Europe differ substantially in their investment patterns when compared with one another and that, in terms of investment patterns, governmental VC investors appear to be the most distinct type of VC investor. The investment patterns of different VC investors are stable over time and similar across different European countries. Finally, the investment patterns of the different VC investor types in Europe are significantly different from those observed in the US.
\end{abstract}

Keywords: Venture capital, Europe, Relative specialization index, Young high-tech companies

JEL codes: G24, G32

\footnotetext{
* Corresponding author. EMLYON Business School - Department of Economics, Finance and Control. Mail: quas@em-lyon.com. Address for correspondence: 23 Avenue Guy de Collongue, 69134 Ecully - France.

We acknowledge support from the 7th EU Framework Programme VICO project on "Financing Entrepreneurial Ventures in Europe: Impact on Innovation, Employment Growth, and Competitiveness" (Contract no. 217485).
} 


\section{Introduction}

Differences in ownership and governance are arguably the most important factor differentiating venture capital (VC) investors, and these differences influence their objectives and their investment strategies (Da Rin et al. 2013). Different configurations of ownership and governance give rise to different types of VC investors. The most familiar VC investor type is the independent VC (IVC), an investor acting as general partner in a limited partnership in which the fund providers serve as limited partners (Sahlman, 1990). Nonindependent, or captive, VC investors are structured as investment vehicles or as business units of a parent company. The parent company is a non-financial company in the case of a corporate $\mathrm{VC}(\mathrm{CVC})$ investor, a financial intermediary in the case of a bank-affiliated VC (BVC) investor, and a governmental agency or body in the case of a governmental VC (GVC) investor. The parent company of a captive VC investor provides capital and has substantial influence on the selection and management of investments (Gompers, 2002; Leleux \& Surlemont, 2003; Hellmann et al. 2008; Dimov \& Gedajlovic, 2010; Dushnitsky, 2012).

Most of the empirical evidence regarding how different types of VC investors operate is based on US data. This circumstance is particularly unfortunate because captive investors are more common, and thus easier to observe, outside of the US (Da Rin et al., 2013). The few studies conducted outside of the US typically focus on a single country and one specific dimension of the issue, which limits the extent to which their results can be used to obtain a systematic view of the patterns of VC investment outside of the US.

In this stream of the literature, the work by Mayer et al. (2005) is an exception. These authors study the investment patterns of VC investors in relation to their source of financing in Germany, Israel, Japan and the United Kingdom. They examine the investment decisions of different VC investor types as related to the stage, industry and location of the target company and find substantial differences in the ways in which the various types of VC investors 
operate in different countries. Contrary to their expectations, the differences that they find in these investment patterns do not follow the conventional distinction between bank- and market-based financial systems. The greatest similarities are found in the investment patterns of $\mathrm{VC}$ investors in the two European countries in their study (Germany and the United Kingdom). The results reported by Mayer et al. (2005) suggest that there might be a European pattern of $\mathrm{VC}$ investment, the description of which is beyond the aim of their paper. Moreover, the papers on VC in Europe (e.g., Lehmann, 2006; Cumming and Johan, 2007; Bottazzi et al., 2008; Schwienbacher, 2008; Schwienbacher et al., 2009; Alperovich and Hübner, 2013; Bertoni et al., 2013; Devigne et al., 2013; Croce et al., 2013; Luukkonen et al., 2013; Bertoni and Tykvová, 2015) have focused more on value creation by different types of VC investors than on their investment patterns.

As a result, the literature still lacks systematic evidence of the investment patterns of different types of VC investors in Europe. In this study, we contribute to filling this gap by examining the patterns of VC investment across different types of $\mathrm{VC}$ investors in Europe and comparing them to the investment patterns observed in the US. More specifically, we analyze the investment patterns of four VC investor types (IVC, CVC, BVC and GVC) with respect to the following investee company characteristics: industry, age, size, stage of development, distance from the investor and country (i.e., domestic or cross-border). We also investigate how the investment patterns of different VC investor types vary over time and across different European countries. In addition, we compare these investment patterns with those exhibited by the same four types of VC investors in the US (relating to industry and age of the investee company). This analysis allows us to assess whether different $\mathrm{VC}$ investor types have a distinct investment pattern in Europe compared to the US, which could contribute to explaining some of the differences in the VC market in the two continents. 
In our analysis, we rely on relative specialization indices (Balassa, 1965), which are popular in the international trade and innovation literature (see Section 3). To the best of our knowledge, these indices have never been used in the entrepreneurial finance literature. By using these indices we can determine, within an investment dimension (e.g., industry), the relative propensity of a focal investor type (e.g., IVC) to invest in a particular category of investee company (e.g., ICT manufacturing) in comparison to all investors. Relative specialization indices also allow investment patterns to be compared over time and across different countries.

In this study, we utilize the VICO database, a comprehensive dataset on the investments of different types of $\mathrm{VC}$ investors in young high-tech companies located in Europe. The primary advantage of using the VICO database for this study is that it overcomes the well-known deficiencies of commercial databases as regards the coverage of VC outside the US, including overrepresentation of IVC investments and mischaracterization of captive investors (see Section 4 for details). We obtain information from the VICO database on 1,663 first VC investments made between 1994 and 2004 by $846 \mathrm{VC}$ investors into 737 entrepreneurial companies located in seven European countries (i.e., Belgium, Finland, France, Germany, Italy, Spain and the United Kingdom) that were less than 10 years old by the time of the first $\mathrm{VC}$ investment and that were operating in high-tech manufacturing and service industries.

The remainder of this paper proceeds as follows. We summarize the key characteristics of the European VC market in section 2. In section 3, we describe the methodology used to examine the investment patterns of the different VC investor types. In section 4, we present the dataset. Section 5 illustrates the empirical results. Section 6 is devoted to a discussion of our results in light of the extant literature. Finally, Section 7 
highlights the contribution of this paper to the VC literature, its policy implications and some possible avenues for future research.

\section{The European Venture Capital Market}

Europe is one of the regions in the world in which VC is most developed. Of the 20 developed countries with the highest VC investment relative to GDP, 13 are located in Europe (OECD, 2013). There is, however, a significant difference in the development of VC between Europe and the US. The VC investment to GDP ratio ${ }^{1}$ is more than four times higher in the US $(0.17 \%)$ than in the United Kingdom $(0.04 \%)$ and more than 10 times higher than in Spain or Italy (approx. 0.01\%) (OECD, 2013).

Differences in the legal and economic framework may explain some of the disparity in the development of VC between Europe and the US (Bruton et al., 2005). Venture capital requires a business-friendly legal environment (Armour and Cumming, 2006). Despite the significant regulatory efforts made by European countries to improve their attractiveness to VC, Europe still has not closed the historical gap with the US in terms of factors such as the level of shareholder protection, the effectiveness of corporate governance, bankruptcy law, and labor market rigidities (Bertoni and Croce, 2011). In addition to regulation, VC is extremely sensitive to the development of capital markets (Black and Gilson, 1998; Jeng and Wells, 2000). Higher volumes of IPOs and M\&As accelerate and improve exits for VC investors (Giot and Schwienbacher, 2007; Bertoni and Groh, 2014). However, capital markets in continental Europe are historically bank-based rather than market-based (Demirgüç-Kunt and Levine, 1999), and this factor has reportedly hampered the development of liquid capital markets. In sum, according to the latest VC \& PE Country Attractiveness Index

\footnotetext{
${ }^{1}$ The use of VC investments to GDP to gauge VC market development is discussed by Cumming (2011).
} 
(Liechtenstein et al. 2014), Western Europe (with an index of 81.0) is substantially behind North America (98.3).

Finally, the structure of the VC market appears to be different in the US and Europe. Since the 1990s, captive investors have accounted for a larger share of the VC market in Europe than in the US (Bottazzi and Da Rin, 2002). This difference may have increased even further in recent years with the substantial growth of government funding. The latest statistics from the European Venture Capital Association (EVCA) show that approximately $40 \%$ of all funds raised by VC investors in Europe in 2013 came from governments; moreover, since 2009, taxpayer money has systematically been the single largest source of VC funds on the continent (EVCA, 2014).

\section{Methodology}

We employ relative specialization indices to examine the investment patterns of the different types of VC investors in Europe. Relative specialization indices were originally used to compare trade flows and to evaluate the revealed comparative advantages of different countries. The idea behind the use of relative specialization indices is that if a country's share of world exports of a particular good is greater than that country's overall share of world exports, then the country has revealed its comparative advantage in exporting this good (Balassa, 1965). Due to their easy construction and interpretability, relative specialization indices have attracted substantial interest beyond the trade literature, including innovation scholars who have used them to examine countries' and firms' specialization in various technological fields (see the revealed technological advantage literature, e.g., Soete and Sally, 1983; Cantwell, 1989; Pavitt, 1988; Archibugi and Pianta, 1992).

The unit of analysis of this study is the VC investor type. Accordingly, we compute the relative specialization indices at the $\mathrm{VC}$ investor type level and use them to compare the patterns of investment of different VC types. Investment patterns are defined along six 
dimensions that characterize investee companies: the (1) industry, (2) age, (3) stage and (4) size of the investee company at the time of the investment; (5) the geographical distance between the investee company and the VC investor; and (6) whether the investment is domestic or cross-border. For each dimension, we define a list of mutually exclusive categories (e.g., for the industry dimension, the categories are different industries and for the age dimension, the categories are different age classes).

The most widely used family of specialization indices is derived from a measure that was initially proposed by Balassa (1965). We indicate by $N_{j, k}^{i}$ the number of investments by investor $i=1, \ldots 4$ that belong to category $k=1, \ldots, M_{j}$ of dimension $j=1, \ldots 6 .^{2}$ The Balassa Index (BI) is defined as follows:

$$
B I_{j, k}^{i}=\frac{N_{j, k}^{i}}{\sum_{k=1}^{M_{j} N_{j, k}^{i}}}\left(\frac{\sum_{i=1}^{4} N_{j, k}^{i}}{\sum_{i=1}^{4} \sum_{k=1}^{M_{j}} N_{j, k}^{i}}\right)^{-1}
$$

The first term on the right hand side of Equation (1) measures the share of the investments made by investor type $i$ in category $k$ of dimension $j$ over the total number of investments made by investor type $i$. The second term is the inverse of the share of the investments made by all VC investors in category $k$ of dimension $j$ over the total number of $\mathrm{VC}$ investments. For example, $B I_{1,1}^{1}$, the specialization of $\mathrm{VC}$ investor type $i=l$ (the IVC) for category $k=1$ (ICT manufacturing) of dimension $j=1$ (the industry), is computed as the share of IVC investments in ICT manufacturing divided by the share of investments in ICT manufacturing made by all VC investors. ${ }^{3}$

\footnotetext{
${ }^{2}$ The value of $M_{j}$ for the 6 dimensions is as follows: $\mathrm{M}_{1}=6$ (industry), $\mathrm{M}_{2}=4$ (age), $\mathrm{M}_{3}=4$ (size), $\mathrm{M}_{4}=4$ (distance), $\mathrm{M}_{5}=3$ (stage), $\mathrm{M}_{6}=2$ (country). Thus we have a total of 23 distinct categories for the 6 dimensions.

${ }^{3}$ In our sample, the number of IVC investments in ICT manufacturing $\left(N_{1,1}^{1}\right)$ is 163 ; the total number of IVC investments $\left(\sum_{k=1}^{M_{j}} N_{j, k}^{1}\right)$ is 918 ; the number of VC investments in ICT manufacturing $\left(\sum_{i=1}^{4} N_{1,1}^{i}\right)$ is 284 and the total number of VC investments $\left(\sum_{i=1}^{4} \sum_{k=1}^{M_{j}} N_{j, k}^{i}\right)$ is $1,663 . B I_{1,1}^{1}$ is therefore equal to $163 / 918 /(284 / 1,663)=$ 1.040 .
} 
The Balassa index is easy to compute and has an intuitive interpretation, but its use in empirical analysis has some shortcomings (Dalum et al., 1998). In our study, a major problem with the Balassa index arises due to the uneven number of investments made by different VC investor types. The problem arises because sampling and measurement errors have a larger impact on categories for which the number of observations is small. ${ }^{4}$ The Balassa index also tends to have an asymmetric and skewed distribution (Grupp, 1994). To alleviate these problems, we follow Dalum et al. (1998) and transform the Balassa index as follows:

$$
T B I_{j, k}^{i}=\frac{B I_{j, k}^{i}-1}{B I_{j, k}^{i}+1}
$$

The transformed Balassa index (TBI) ranges from -1 to +1 , and 0 is its neutral value. Positive (negative) values of TBI indicate that investor type $i$ is more (less) specialized in category $k$ of dimension $j$ than other investor types. The TBI computed in Equation (2) exhibits two primary advantages over the untransformed Balassa index. First, it attributes the same weight to changes below the neutral value as it does to changes above the neutral value. Second, TBIs are asymptotically normal under a more general set of assumptions than the Balassa index itself (Dalum et al., 1998; Schubert and Grupp, 2011). We can then use the asymptotically normal distribution of the TBI to test the null hypothesis that for a given VC investor type in a given category of a given dimension, the value of the relevant TBI is equal to 0 . To compute these t-tests for the null hypothesis that $\mathrm{TBI}=0$ we use the procedure described by Schubert and Grupp (2011). ${ }^{5}$

\footnotetext{
${ }^{4}$ For instance, in our sample, the number of IVC investments is larger than the number of CVC investments by a factor of 5.6 (918 vs. 165), which means that the same measurement error would have an impact on CVC's BI that is larger by a factor of 5.6 than its impact on IVC's BI.

${ }^{5}$ In our data, the TBI correlates with the original BI at $95.69 \%$. The transformation that we adopt to compute TBI is common in the literature, but other transformations are also possible. For example, the Balassa index can be subjected to a logarithmic transformation (Vollrath, 1991) or a hyperbolic tangent transformation (Grupp, 1994). We replicated our analyses using these alternative transformation methods. The TBI that was used here correlates with both Grupp's (1994) and Vollrath's (1991) specifications at a 99\% level and the results we obtained are virtually the same. For the sake of synthesis, we do not report the results obtained under these different transformations, which are available upon request.
} 


\section{Data and Descriptive Statistics}

Our sample of VC investments is extracted from the VICO database. This database is part of a project financed by the 7th Framework Programme promoted by the European Commission (see www.vicoproject.org), and it has been used by several recent works (e.g., Croce et al., 2013; Grilli and Murtinu, 2014; Cumming et al., 2014; Colombo et al., 2014a; Grilli and Murtinu, 2015). ${ }^{6}$ The VICO database includes 759 VC-backed companies that received their first round of VC investment between 1994 and 2004 and were less than 10 years old at that time. The companies cover all of the early stages of VC investments: seed, start-up, and expansion. The companies are randomly drawn both from commercial databases that are widely used in scholarly work (Thomson One, VCPro-Database and Zephyr) and from country-specific proprietary datasets (the yearbooks of the Belgium Venture Capital and Finnish Venture Capital Associations, the ZEW Foundation Panel for Germany, the RITA directory and Private Equity Monitor for Italy, the Web Capital Riesgo Database for Spain, and Venture Source in the United Kingdom). The data on VC investments were cross-checked with information available on ventures' and investors' websites, press releases and other public information sources.

A central data-collection unit assured the consistency and reliability of the collected data. This quality assurance effort and the use of a plurality of information sources overcome the limitations of commercial databases. As is well known, commercial databases provide inadequate coverage of VC investments outside of the US. In particular, they tend to overrepresent the role of IVC investors and give only partial coverage of, and often mischaracterize, captive investors (e.g., Ivanov and Xie, 2010; Da Gbadija, et al., 2014). For example, if we consider the investments in young high-tech companies conducted in Europe between 1994 and 2004, the share represented by IVC investors is $72 \%$ according to

\footnotetext{
${ }^{6}$ A full description of the database is provided by Bertoni and Martí Pellón (2011).
} 
Thomson One but only 55\% according to VICO. GVC is the category of VC investor that is most underrepresented by commercial databases. If we consider again the investments in young high-tech companies conducted in Europe between 1994 and 2004, the share of GVC is $2 \%$ according to Thomson One and $19 \%$ according to VICO.

$\mathrm{VC}$ investors are identified and classified according to the ownership and governance of the management company. An investor characterized by an independent management company is classified as an IVC investor. Captive investors are classified depending on the identity of the entity that controls their management processes. Investors whose parent companies are non-financial companies are classified as CVC investors, and those whose parent companies are financial intermediaries as BVC investors. If the parent is a governmental agency or institution, the investor is classified as a GVC investor. ${ }^{7}$

Our initial population consists of all first investments by IVC, CVC, BVC and GVC investors in companies included in the VICO dataset. Investments for which we do not know the VC investor type are excluded from the analysis. In particular, we consider the first round in which a given VC investor invested in a given company for the first time. We exclude from the analysis all follow-on rounds in which a given investor participates (see Dimov and Gedajlovic, 2010, for a similar approach). The rationale behind this approach is that an investor reveals the structure of his/her investment preferences when he or she first invests in a company. The inclusion of follow-on rounds in the computation of specialization indices would instead result in the overrepresentation of cases in which VC investment is split over several rounds. The number of investment rounds is the outcome of a complex contracting process engaged in by the investor and the investee company (Gompers, 1995). The staging of VC investments can vary systematically across industries, countries and phases of the

\footnotetext{
${ }^{7}$ There is generally a close correspondence between the type of $\mathrm{VC}$ investor and the origin of the funds it invests. Captive investors generally invest funds obtained from their parent company (CVC or BVC) or public sources (GVC). See Mayer et al. (2005).
} 
economic cycle. Including all investment rounds, rather than just the first investment, would thus give us no additional information about the structure of investors' preferences and would expose us to measurement biases.

After eliminating the cases that do not meet the criteria discussed above, we are left with a sample of 1,663 first VC investments made by $846 \mathrm{VC}$ investors into 737 companies. The VICO database provides detailed information about investee company characteristics that are used here to study the investment patterns of different types of VC investors in Europe.

\section{Insert Table 1 here}

Table 1 shows the distribution of the 1,663 VC investments included in the VICO database according to the VC investor type and the country of the investee firm. The majority of the VC investments are made by IVC firms (55.2\%). The second most represented VC investor type is GVC (19.5\%), followed by BVC (15.4\%). The relatively high number of BVC and GVC investments is an interesting peculiarity of the European VC market (see Section 6 for a comparison with the US). CVC investors cover the remaining $9.9 \%$ of investments. With respect to the country of the investee company, the most represented countries are the United Kingdom (24.8\%), France (23.6\%) and Germany (17.7\%).

Table 1 also shows the distribution of investments across the categories defined for each of the six dimensions considered. The distribution of investments across industries highlights the interest of European VC in the software (34.2\%) and biotechnology and pharmaceuticals (24.4\%) industries. Companies operating in Internet and telecommunication (TLC) services $(20.6 \%)$ and ICT manufacturing ${ }^{8}(17.1 \%)$ are also important targets of VC investments. Investee companies are typically very young at the time of the investment: only $15.7 \%$ of the investments are in companies older than 5 years, whereas $22.7 \%$ of the investments are in newly funded companies (less than 1 year old). Investee companies are

\footnotetext{
${ }^{8}$ ICT manufacturing includes the following industries: electronic components, computers, telecommunications equipment, and electronic, medical and optical instruments.
} 
also rather small: $38.7 \%$ of the investments are in micro companies with fewer than 10 employees, $48.6 \%$ are in small companies (i.e., between 10 and 49 employees), and only $12.8 \%$ are in companies with 50 or more employees. A total of $24.2 \%$ of the $\mathrm{VC}$ investments occur during the seed stage, $37.0 \%$ during the start-up stage and $38.8 \%$ during the expansion stage. Another variable that has attracted the interest of $\mathrm{VC}$ scholars is the geographic distance between the investee company and the VC investor (e.g., Sorensen and Stuart, 2001). In $29.0 \%$ of investments, the VC investor is located less than $10 \mathrm{~km}$ away from the investee company, and in $19.6 \%$ of investments, the distance is between 10 and $50 \mathrm{~km}$. The distance is more than $300 \mathrm{~km}$ for only $22.6 \%$ of investments. Lastly, the vast majority $(77.5 \%)$ of the investments in our sample are domestic. These data confirm the local bias of VC investors and their limited internationalization, which is also highlighted by previous studies. ${ }^{9}$

\section{Results}

\subsection{The Investment Patterns of Different VC Investor Types in Europe}

The results of the analysis are illustrated in Table 2 . In addition to the value of the TBIs, the table shows their standard deviations (Schubert and Grupp, 2011) and the result of a t-test of the null hypothesis that the corresponding TBI is equal to 0 . Overall, the results show that each VC investor type has a defined pattern of investment with respect to the dimensions considered.

Compared to other VC investor types, IVC investors are more inclined to invest in Internet and TLC services and less inclined to invest in R\&D and engineering services. IVC investors shy away from the riskiest investments in the youngest companies at their seed stage and are specialized in more mature companies. The TBI of IVC in companies three to five years old is 0.046 , implying that IVC's tendency to invest in this age category is $9.7 \%$ greater

\footnotetext{
${ }^{9}$ For instance, Schertler and Tykvová (2010) found that approximately two thirds of global VC deals between 2000 and 2008 included only domestic investors.
} 
than that of the entire sample. ${ }^{10}$ Similarly, IVC's TBI in the expansion stage is 0.037 , which corresponds to a tendency to invest in this category of development stage that is greater by $7.6 \%$ than that of the entire sample. The TBIs of IVC investors increase monotonically with the size of the investee company and are negative and significant for companies with fewer than ten employees. IVC investors do not exhibit any inclination to select local companies: their TBIs are negative and significant for the first two categories of distance and positive and significant for the remaining two categories, indicating a relative specialization in investments in more distant companies. The effect is economically meaningful: their TBI in the $0-10 \mathrm{~km}$ category is -0.053 , which corresponds to a tendency to invest in companies included in this distance category that is smaller by $10.0 \%$ than that of the entire sample. IVC investors are $13.5 \%$ more inclined than the overall sample to invest in companies included in the $50-300$ km category $(\mathrm{TBI}=0.040)$.

CVC investors are $35.2 \%$ more prone than the entire sample to invest in Internet and TLC services $(\mathrm{TBI}=0.150$ ), while they are $30.4 \%$ less likely to invest in biotech and pharmaceuticals (TBI=-0.179). CVC investors do not exhibit any specific investment pattern with regard to the age, stage and size of investee companies. However, they exhibit the most marked preference for distant companies: their TBI is positive and significant for companies located farther than $300 \mathrm{~km}$ from their premises. Similarly, CVC investors are $77.4 \%$ more inclined than the entire sample to invest in cross-border investments $(\mathrm{TBI}=0.279)$.

BVC investors do not exhibit a distinct pattern of industry specialization. However, they show the strongest preference for non-risky investments: they have a clear aversion to newly created companies ( $\mathrm{TBI}=-0.197$, indicating that they are $32.9 \%$ less present than the entire sample in this category) and for companies with fewer than ten employees (TBI=-

\footnotetext{
${ }^{10}$ Using Equation (2), we obtain that a TBI of 0.046 corresponds to a BI of 1.097, which implies that IVC's share of VC investments in companies aged 3-5 years is $9.7 \%$ greater than the overall share of IVC investments out of the total number of $\mathrm{VC}$ investments.
} 
0.151, indicating that they are $26.3 \%$ less inclined than the entire sample to invest in companies included in this category), whereas they specialize in companies older than five years and with fifty or more employees. BVC investors also have a preference for local investments. In particular, they are attracted to companies that are located between 10 and 50 $\mathrm{km}$ from their premises, and they abstain from investing in companies in the $50-300 \mathrm{~km}$ category $(\mathrm{TBI}=-0.209$, indicating that they are, on average, $44.2 \%$ less likely than the entire sample to invest in companies that belong to this category).

The investment pattern of GVC investors diverges the most from that of all other investor types. In terms of industry specialization, GVC investors neglect Internet and TLC services and focus instead on $\mathrm{R} \& \mathrm{D}$ and engineering services, biotechnology and pharmaceuticals and other high-tech manufacturing. GVC investors specialize in the youngest companies in the seed stage, while they ignore more mature companies and companies in the expansion stage. With a TBI of $0.185, \mathrm{GVC}$ investors are $45.3 \%$ more inclined than the entire sample to invest in companies younger than 1 year. Similarly, the TBIs of GVC investors decrease monotonically with investee company size: they are positive and significant for the smallest companies (fewer than ten employees) and negative and significant for the largest companies (more than twenty-five employees). They also are the investors most strongly oriented toward local investments. Their TBI is positive and significant for investments in companies located closer than $10 \mathrm{~km}$ from their premises and is negative and significant for investments farther than $300 \mathrm{~km}$ away. Similarly, GVC investors are the investors most specialized in national companies. With $\mathrm{TBI}=0.077$, they are $73 \%$ more oriented to invest domestically than the entire sample.

\section{Insert Table 2 here}

Next, we measure the extent to which VC investor types differ from one another by computing the correlation between their TBIs. Each VC investor type $i$ is characterized by a 
vector $T B I_{j, k}^{i}$ of the 23 TBIs for all of the categories of all the dimensions under consideration (i.e., $\sum_{j=1}^{6} M_{j}=23$, see footnote 2 ). We examine the similarity of these vectors by computing their correlations. Because the number of elements in $T B I_{j, k}^{i}$ is small, we use Spearman's rank correlation. ${ }^{11}$ The results are reported in Table 3.

The correlations between the investment patterns of private investors are not significant, which suggests that their investment patterns are independent. By contrast, the investment pattern of GVC investors correlates negatively with those of the IVC and BVC investor types, with their Spearman's rank correlation being significant at $1 \%$. This result suggests that the investment pattern of GVC investors is the reverse of that of IVC and BVC investors, which means that GVC investors specialize in the niches of the market in which IVC and BVC are least likely present.

\section{Insert Table 3 here}

\subsection{Stability of Investment Patterns over Time and across Countries}

In this section, we examine the stability of the investment patterns over time and across the different countries in our sample. The burst of the Internet bubble in the late 1990s is thought to have been followed by a substantial refocus of the investment strategies of VC investors (e.g., Green, 2004). To check whether such a structural break occurred in the investment pattern of the different VC investor types, we computed two vectors of TBIs by splitting the sample into two periods: before the burst of the Internet bubble (1994-2001) and after (20022004). We then computed the Spearman's correlation indices for the value of the TBIs relating to each investor type between the two periods. If a structural break occurred, the TBIs in the two periods would derive from independent investment processes and we would expect no statistically significant correlation between the corresponding TBIs. Accordingly, we can

\footnotetext{
${ }^{11}$ As a robustness check of the following analysis, we used Kendall's tau rank correlation instead of Spearman's rank correlation. The results are robust and available from the authors upon request.
} 
reject the null hypothesis that a structural break occurred if we can reject the null hypothesis that the correlation between the TBIs in the two periods is zero. The results are reported in Table 4.

The overall correlation, computed from 92 observations, is positive and significant at the $1 \%$ confidence level, indicating that the investment patterns of the $\mathrm{VC}$ investor types are persistent. When distinguishing between different types of VC investor, the TBIs of IVC, BVC and GVC investors exhibit positive and significant correlations between the two periods (the correlation is significant at $1 \%$ for IVC and GVC investors, and at $10 \%$ for BVC investors). However, the correlation for CVC investors is not statistically significant, which indicates that we cannot reject the null hypothesis that with the burst of the Internet bubble a structural break occurred in the investment pattern of CVC investors.

\section{Insert Table 4 here}

Next, we focus on inter-country differences in the investment patterns of $\mathrm{VC}$ investor types. To check the inter-country similarity of investment patterns, for each country we calculate the vector of TBIs based only on the observations related to that country and compare it, using Spearman's correlation, to the vector obtained for the observations related to the other countries in our sample. If the investment processes were independent across countries, we would expect no statistically significant correlation between the corresponding TBIs. Accordingly, we can reject the null hypothesis that the investment processes are independent across countries if we can reject the null hypothesis that the correlation between their TBIs is zero. The results are presented in Table $5 .^{12}$

Overall, the TBIs in each country are similar to the TBIs in the other countries under consideration, with a correlation of 0.32 , which is significant at $1 \%$. This result suggests that

\footnotetext{
12 To avoid small numbers, we reclassified the industry dimension from 6 to 5 categories, which brings the total number of categories from 23 to 22 .
} 
the investment patterns of different VC investor types are not independent across Europe, and that different investor types, on average, behave similarly in different European countries. When we separately consider the TBIs of each country, all correlations are positive and significant at conventional confidence levels, which means that for each country we can reject the null hypothesis that the investment patterns of VC investors in that country are independent from those in the rest of the sample. Finally, when we separately consider the TBIs related to each VC investor type, we notice that investment patterns are significantly correlated across countries for each VC investor type (significance is $1 \%$ for IVC, BVC and GVC and $10 \%$ for CVC).

\section{Insert Table 5 here}

\subsection{A Comparison of the Investment Patterns of Different VC Investor Types between Europe and the US}

The aim of this section is to compare the investment patterns that we find in our study with evidence about VC investments in the US. For this purpose, we resort to the Thomson One database (previously VentureXpert, retrieved on December 23, 2011), which has been extensively used in the VC literature. According to this database, between 1994 and 2004, 3,457 VC investors belonging to the four types of $\mathrm{VC}$ investor considered in this paper were responsible for 24,242 first $\mathrm{VC}$ investments in 9,024 companies less than 10 years old, operating in high-tech sectors, and located in the US. The distribution of these investments according to the $\mathrm{VC}$ investor type, industry and age of investee company at the time of investment are reported in Table $6 .{ }^{13}$ Of these investments, $68.0 \%$ were made by IVC investors, $17.4 \%$ by $\mathrm{CVC}$ investors, $12.2 \%$ by BVC investors and the remaining $2.5 \%$ by GVC investors. A $\chi^{2}$ test indicates that this distribution is significantly different from the corresponding distribution in Europe (p-value $<1 \%$ ). In particular, IVC and CVC investments

\footnotetext{
${ }^{13} \mathrm{We}$ do not consider here the investee company's stage of development at the time of the VC investment because the classification is not entirely comparable across the Thomson One and VICO datasets.
} 
are less frequent in Europe than in the US, whereas BVC and, more remarkably, GVC investments are more frequent in Europe. There are also significant differences between the US and Europe relating to the distribution of $\mathrm{VC}$ investments by industry and age of the investee companies.

\section{Insert Table 6 here}

Similar to the previous sections, we compute the TBI for each VC investor type in the US for the two dimensions for which a meaningful comparison was possible, and we test their significance. Table 7 presents the TBIs for the VC investor types in the US. We then compute the Spearman's correlation indices of the TBIs in the US and Europe for the four VC investor types under consideration in this study. The investment patterns in the US and Europe for the four investor types differ substantially. The overall correlation indices computed on 40 observations ${ }^{14}$ is equal to 0.09 and is not significant at customary confidence levels. We also compute the correlation indices for each TBI dimension. We find that the investment patterns in the US and Europe are not correlated along either the industry $(0.17$, non significant) or age (-0.17, non significant) dimensions. When we separately consider the TBIs related to each VC investor type, the only significant correlation is that between GVC investors in Europe and the US (the Spearman's correlation index is equal to 0.61 , significant at $10 \%$ ). The TBIs of all other investor types in the two geographical areas do not significantly correlate.

\section{Insert Table 7 here}

Table 7 shows that the only industries in which the investment patterns of $\mathrm{VC}$ investor types are similar are the biotechnology and pharmaceutical and the Internet and TLC service industries. As for age, the most striking difference is the inverted role of IVC and GVC investors in the two institutional contexts. In the US, IVC investors specialize in very young companies and abstain from investing in 3- to 5-year-old companies, whereas by contrast,

\footnotetext{
${ }^{14}$ There are 6 categories for the industry dimension, 4 categories for the age dimension and 4 VC investor types.
} 
GVC investors specialize in these companies. This evidence confirms that IVC in Europe is less attracted to risky investments than in the US (see, e.g., Bruton et al., 2005).

\section{Discussion}

The results illustrated in the previous sections highlight significant differences across the investment patterns of different types of $\mathrm{VC}$ investors in Europe. They also highlight significant differences in the investment patterns of the VC investor types between Europe and the US.

In Europe, IVC investors abstain from making risky investments and tend to select mature and large companies in the expansion stage. This investment pattern differs markedly from that exhibited by IVC investors in the US, in which IVC appears to be relatively more inclined to risk taking. Another interesting difference between Europe and the US is that the popular Silicon Valley "20-minute rule", according to which start-up companies located farther than a 20-minute drive from the VC firm will not be funded by IVC investors, ${ }^{15}$ is not confirmed by our data on the investments made by IVC investors in Europe (see Fritsch and Schilder, 2008, for similar evidence based on German data).

Previous studies (e.g., Dushnitsky and Lenox, 2005) found that CVC investors in the US are particularly attracted to companies operating in industries with high technological ferment and weak intellectual property protection. This evidence, based on US data, is confirmed by our findings on European investments. In Europe, CVC investors were indeed found to specialize in Internet and telecommunication services, an industry with a weak appropriability regime (Malerba, 2004) and high technological turbulence in the observation period (Montobbio, 2004), and to abstain from investing in biotechnology and pharmaceuticals, where intellectual property can be effectively protected (Levin et al., 1987).

\footnotetext{
15 “It's not the people you know. It's where you are." The New York Times, 10/22/2006.
} 
Our results are also consistent with previous empirical literature based in the US (Gupta and Sapienza, 1992) and in other countries (Mayer et al., 2005) indicating that CVC investors adopt a more global investment strategy than the other investor types and are more inclined to select companies located far away from their premises. Conversely, our results relating to Europe do not support the US-based evidence that CVC investors are less likely to invest in early stage companies than IVC investors (see, e.g., Cumming, 2006, on Canada; Katila et al., 2008, and Ferrary, 2010, on the US). This result is most likely a consequence of the abovementioned risk aversion of European IVC investors.

We found that BVC investors in Europe, when compared with other types of private VC investors, are more likely to invest locally, where they can exploit their superior ability to gather soft information (Coval and Moskowitz, 2001; Fritsch and Schilder, 2008). Moreover, our results clearly document that BVC investors are more inclined to invest in older and larger companies. This result conforms to the view that the primary objective of BVC investors is to support the establishment of profitable bank relationships with investee companies (Mayer et al., 2005, and Hellmann et al., 2008, find similar results in a sample of international and US firms, respectively).

Finally, in Europe, GVC investors exhibit an investment pattern that differs remarkably from that of all other types of VC investors. Previous studies argued that the rationale for GVC is to fill the funding gap left by private investors (Lerner, 1999; Lerner, 2002). Consistent with this argument, we find that GVC investors in Europe specialize in investments that do not attract other types of investor. Because of the information asymmetries surrounding young, small high-tech companies and their high risk of failure, these companies find it difficult to attract private funding, particularly at the seed stage (e.g., Carpenter and Petersen, 2002). These difficulties are amplified in industries such as biotechnology, in which time to market is long and substantial resources are required for new 
product development. Our analysis shows that these industries are precisely those in which European GVC investors specialize. Moreover, consistent with previous studies based both in Europe and the US (e.g., Gupta and Sapienza, 1992; Mayer et al., 2005; Fritsch and Schilder, 2008), we find that GVC investors more frequently select local investment targets, which is consistent with the fact that GVC programs have often been created to implement regional development objectives (Leleux and Surlemont, 2003).

\section{Conclusions}

In this study, we analyzed the investment patterns of four types of VC investor (IVC, CVC, BVC and GVC) in Europe between 1994 and 2004, and we compared these patterns with those of the corresponding VC investor types in the US. We have shown that, in Europe, VC investor types exhibit different investment patterns in terms of industry, age, size, stage of development, and localization of their investee companies. In addition, these investment patterns are quite stable over time (with the exception of those of CVC investors, which changed significantly after the burst of the Internet bubble) and similar across different European countries. However the investment patterns differ markedly between Europe and the US. Most notably, the role played by IVC in the US, where this investor type invests in the youngest and riskiest companies, is different from the role it plays in Europe, where it tends to invest later, leaving the riskiest investments to GVC.

This study offers two original contributions to the VC literature. First, the VC literature has recognized that the ownership and governance of VC firms is an important source of heterogeneity in VC markets (Dimov and Gelajdovic, 2010). In this paper, we have provided a comprehensive overview of the investment patterns of IVC, CVC, BVC and GVC investors using relative specialization indices. These indices are particularly appropriate for this type of analysis because they allow the investment patterns of different types of VC investors to be systematically and parsimoniously compared and the statistical significance of 
any differences between these patterns to be tested. As far as we know, this study represents the first time that such tools have been used in the entrepreneurial finance domain.

Second, this study offers an original contribution to the debate about GVC. Over the past two decades, several GVC firms (and other government-supported VC firms) have been created in Europe and several other countries with the aim of developing active VC markets (Brander et al., 2014). The available evidence suggests that the impact of GVC investments on the economic performance of investee companies has been dismal (e.g., Grilli and Murtinu, 2014; Cumming et al., 2014. See Cumming, 2007 for an exception). ${ }^{16}$ While providing a systematic illustration of the patterns of investment of GVC investors in Europe during a period in which European governments were active in fostering VC investor activity, our study offers a new perspective on these results. GVC investors have specialized in investing in industries (biotechnology and pharmaceuticals) and types of companies (young, small, seed-stage companies) that have proven unattractive to private VC in Europe. This evidence indicates that in Europe, GVC has filled the entrepreneurial financing gap left by private VC investors. Therefore, the above-mentioned limited "treatment effect" of GVC investments should come as no surprise. However, our results also suggest that GVC investors have not been able to attract private VC to the young, small, early stage companies that were the target of their investment activity because the different investment patterns of IVC and GVC investors have proven to be stable over time.

\footnotetext{
${ }^{16}$ One possible reason for this result is that GVC investors provide limited value-enhancing services to investee companies (Luukkonen et al., 2013). In accordance with this view, the effects appear to be more positive when GVC investors syndicate with private VC investors. For instance, while analyzing a large sample of VC-backed companies in 25 countries, Brander et al. (2014) documented that these syndicated investments have outperformed other types of $\mathrm{VC}$ investments in terms of the total amount of investment obtained by companies and the likelihood of successful exit (i.e., through IPOs and third-party acquisitions). Bertoni and Tykvová (2015) found similar results with regard to the patenting activity of young European biotechnology and pharmaceutical companies. In Europe, however, GVC investors are unlikely to form syndicates, due to the divergence of their objectives and investment specialization patterns from those of private investors. For an overview of worldwide evidence on GVC investments, see Colombo et al. (2014b).
} 
We believe that our study extends the knowledge of the VC market in Europe. Nonetheless, we are aware of its limitations, which open interesting avenues for future research. First, our results highlight that there are important differences in the investment patterns of several types of VC investors between Europe and the US and that these differences are far more pronounced than those between individual European countries. The analysis of the sources of these differences goes beyond the scope of the paper. On the basis of previous work, one might argue that these differences are possibly the result of differences relating to the institutional environment in which investors operate (Bruton et al., 2005; Da Gbadji et al., 2014). The analysis of this issue is clearly an interesting direction for future research. We think that relative specialization indices represent a valid methodology for performing this type of analysis.

Second, our results indicate that the ownership and governance of VC investors deeply influence their patterns of investment. However, investors differ not only due to ultimate ownership but also due to their experience, reputation, and skills. An interesting further step would consist of an analysis of the heterogeneity of the investments within each VC investor type. Previous studies have shown that the reputation and size of an IVC investor indeed influences its investment strategy (Murray, 1999; Dimov et al., 2007). It would be interesting to extend this analysis to CVC, BVC and GVC investors.

Third, while investment patterns are positively correlated (i.e., not independent) across European countries, this correlation is not perfect. This raises the question about which European country's configuration of investment patterns is most effective in channeling funds (and the non-financial support that comes with it) to entrepreneurial startups. Relatedly, our results highlight a very different role played by IVC and GVC in Europe and the US. While in Europe GVC is more likely than IVC to invest in companies at their earliest stages, the opposite happens in the US. Because IVC and GVC differ markedly in their screening, 
monitoring and coaching skills, this inversion in their role may have relevant consequences on the average quality of startups that receive $\mathrm{VC}$ financing and on their ability to survive and prosper. The comparative analysis of how investment patterns affect the effectiveness of the VC market is beyond the scope of this paper, but represents a very interesting topic for future research.

In spite of these limitations, this study has important implications for European policymakers, and certain guidelines for improving policy intervention are indicated. European policymakers have been trying since well before the Lisbon Agenda (e.g., European Commission, 1998) to create an EU-wide VC market for early stage high-potential companies. Our results are consistent with the view that despite these efforts, the European VC market remains fragmented. First, IVC investors in Europe do not exhibit any pronounced propensity for cross-border investments nor has the existing propensity increased over time. Second, CVC investors, which indeed specialize in cross-border VC investments, account for a smaller share of investments in Europe than in the US. Recently, specific measures have been taken by European policymakers aimed at regulatory simplification and harmonization. In particular, in a series of recent acts (most notably the Small Business Act and the Single Market Act), the European Commission has committed itself to promoting cross-border VC investment by adopting new rules ensuring that $\mathrm{VC}$ funds established in any member state can be invested freely throughout the EU (the so-called pan-European passport for VC investors). Our results suggest that measures such as these are a step in the right direction. Nevertheless, more is needed to overcome the fragmentation of the European VC market. As discussed above, GVC plays a fundamental role in the European VC market. A weakness of governmental intervention in the form of GVC that has not been mentioned in previous studies is the highly localized nature of these GVC investments. GVC investors are the most prone to invest in companies located closer than $10 \mathrm{~km}$ and the least prone to invest abroad, 
which is likely a consequence of the local nature of their mandates. ${ }^{17}$ The local bias of GVC investors creates two types of problems. First, it exposes GVC investors to the risk of regulatory capture (Lerner, 2002), thereby jeopardizing their investment selection capability. Second, it exacerbates the fragmentation of the European VC market. We believe that the removal of the regulatory constraints that led to this local bias would help to make the European VC market less fragmented and more efficient.

\footnotetext{
${ }^{17}$ Investment vehicles founded by a regional or national government are often statutorily prevented or otherwise discouraged from investing outside of regional or national borders. The obvious reason for this prohibition is that policymakers would find it difficult to explain to taxpayers in one region or country why their money is being used to support companies in another region or country. SITRA, a Finnish GVC investor, is an interesting exception. SITRA invests a portion of VC funds outside of Finland, claiming that the objective of these crossborder investments is to create a window to the international VC market and learn about new investment practices. At the end of 2010, the international portion of the assets managed by SITRA had a book value of 42 million Euros, corresponding to $6 \%$ of total assets (SITRA, 2011).
} 


\section{References}

Alperovych, Y. \& Hübner, G. (2013). Incremental impact of venture capital financing. Small Business Economics, 41(3): 651-666. doi: 10.1007/s11187-012-9448-6.

Archibugi, D. \& Pianta, M. (1992). The technological specialization of advanced countries: $a$ report to the EEC on international science and technology activities, Dordrecht, Kluver Academic.

Armour, J., \& Cumming, D. (2006). The legislative road to Silicon Valley. Oxford Economic Papers, 58, 596-635. doi:10.1093/oep/gp1007.

Balassa, B. (1965). Trade liberalization and 'revealed' comparative advantage. Manchester School, 33, 99-123. doi: 10.1111/j.1467-9957.1965.tb00050.x.

Bertoni, F., \& Croce, A. (2011). Policy reforms for venture capital in Europe. In M. G. Colombo, L. Grilli, L. Piscitello, \& C. Rossi-Lamastra (Eds.), Science and innovation policy for the new knowledge economy (pp. 137-161). Cheltenham, UK - Northampton, MA, USA: Edward Elgar.

Bertoni F., Groh, A. (2014). Cross-Border Investments and Venture Capital Exits in Europe. Corporate Governance: an International Review, 22(2), 84-99. doi: 10.1111/corg. 12056.

Bertoni, F., Colombo, M. \& Grilli, L. (2013). Venture capital investor type and the growth mode of new technology-based firms. Small Business Economics, 40(3): 527-552.

Bertoni, F., \& Martí Pellón, J. (2011). Financing entrepreneurial ventures in Europe description of the VICO dataset. SSRN eLibrary, 1-13. Retrieved from: http://ssrn.com/abstract=1904297.

Bertoni F., Tykvová T. (2015). Does Governmental Venture Capital Spur Invention and Innovation? Evidence from Young European Biotech Companies. Research Policy, 44(4): 925-935.

Black, B. S. \& Gilson, R. J. (1998). Venture capital and the structure of capital markets: Banks versus stock markets. Journal of Financial Economics, 47: 243-277. doi:10.1016/S0304-405X(97)00045-7.

Bottazzi, L., \& Da Rin, M. (2002). Venture capital in Europe and the financing of innovative companies. Economic Policy, 17(34), 229-270. doi:10.1111/1468-0327.00088.

Bottazzi, L., Da Rin, M., \& Hellmann, T. F. (2008). Who are the active investors? Evidence from venture capital. Journal of Financial Economics, 89, 488-512. doi: 10.1016/j.jfineco.2007.09.003.

Brander, J. A., Qianquian, D., \& Hellmann, T. F. (2014). The effects of governmentsponsored venture capital: international evidence. Review of Finance, First Published Online, 1-44. doi: 10.1093/rof/rfu009.

Bruton, G. D., Fried, V. H., \& Manigart, S. (2005). Institutional influences on the worldwide expansion of venture capital. Entrepreneurship Theory and Practice, 29(6), 737-760. doi: $10.1111 / \mathrm{j} .1540-6520.2005 .00106 . x$.

Cantwell, J.A. (1989). Technological Innovation and Multinational Corporations, B. Blackwell, Oxford.

Carpenter, R. E., \& Petersen, B. C. (2002). Capital market imperfections, high-tech investment, and new equity financing. The Economic Journal, 112(477), F54-F72. doi: 10.1111/1468-0297.00683.

Colombo, M. G., Piva, E., \& Rossi Lamastra, C. (2014a). The sensitivity of high-tech entrepreneurial ventures' employment to a sales contraction in a negative growth scenario: The moderating role of venture capital financing, Managerial and Decision Economics, 35, 73-87. doi: 10.1002/mde.2645. 
Colombo, M. G., Cumming, D., \& Vismara, S. (2014b). Governmental Venture Capital for Innovative Young Firms, Journal of Technology Transfer, forthcoming. doi: 10.2139/ssrn.2471469.

Coval, J., \& Moskowitz, T. (2001). The geography of investment: informed trading and asset prices. Journal of Political Economy, 109, 811-841. doi: 10.2139/ssrn.214138.

Croce, A., Martì Pellon, J., \& Murtinu, S. (2013). The impact of venture capital on the productivity growth of European entrepreneurial firms: "Screening" or "value added" effect? Journal of Business Venturing, 28(4), 489-510. doi: 10.1016/j.jbusvent.2012.06.001.

Cumming, D. J. (2006). Adverse selection and capital structure: evidence from venture capital. Entrepreneurship Theory and Practice, 30(2), 155-183. doi: 10.2139/ssrn.261693.

Cumming, D. J. (2007). Government policy towards entrepreneurial finance: Innovation Investment Funds. Journal of Business Venturing, 22(2), 193-235. doi: 10.1016/j.jbusvent.2005.12.002. doi: 10.1007/s11408-006-0041-3.

Cumming, D.J. (2011). Public policy and the creation of active venture capital markets. Venture Capital : An International Journal of Entrepreneurial Finance, 13(1), pp.75-94. doi: 10.1080/13691066.2010.492989.

Cumming, D. J., Grilli, L., \& Murtinu, S. (2014). Government and Independent Venture Capital Investments in Europe: A Firm-Level Performance Analysis. Journal of Corporate Finance, forthcoming.

Cumming, D. J., \& Johan, S. (2007). Advice and Monitoring in Venture Finance. Financial Markets and Portfolio Management, 21(1), 3-43. doi: 10.1007/s11408-006-0041-3.

Da Gbadij, L. A. G., Gailly, B., \& Schwienbacher, A. (2014). International analysis of venture capital programs of large corporations and financial institutions. Entrepreneurship Theory \& Practice, forthcoming. doi: 10.1111/etap.12105.

Da Rin, M. D., Hellmann, T., \& Puri, M. (2013). A survey of venture capital research. In G. Constantinides, M. Harris, \& R. Stulz (Eds.) Handbook of the Economics of Finance. Volume 2, Part A (pp. 573-648). Elsevier. doi: 10.1016/B978-0-44-453594-8.00008-2.

Dalum, B., Laursen, K., \& Villumsen, G. (1998). Structural change in OECD export specialisation patterns: de-specialisation and 'stickiness'. International Review of Applied Economics, 12, 423-443. doi: 10.1080/02692179800000017.

Demirgüç-Kunt, A., \& Levine, R. (1999). Bank-based and Market-based Financial Systems: Cross-country Comparisons. Vol. 2143. World Bank Publications.

Devigne, D., Vanacker, T., Manigart, S. \& Paeleman, I. (2013). The role of domestic and cross-border venture capital investors in the growth of portfolio companies. Small Business Economics, 40(3): 553-573.

Dimov, D., \& Gedajlovic, E. (2010). A property rights perspective on venture capital investment decisions. Journal of Management Studies, 47(7), 1248-1271. doi: 10.1111/j.1467-6486.2009.00905.x.

Dimov, D., Shepherd, D., \& Sutcliffe, K. (2007). Requisite expertise, firm reputation, and status in venture capital investment allocation decisions. Journal of Business Venturing, 22, 481-502. doi: 10.1016/j.jbusvent.2006.05.001.

Dushnitsky, G. (2012). Corporate venture capital in the 21st century: an integral part of firms' innovation toolkit. In D. Cummings (Ed.), Oxford Handbook of Venture Capital (pp. 156210). Oxford, UK: Oxford University Press.

Dushnitsky, G., \& Lenox, M. J. (2005). When do firms undertake R\&D by investing in new ventures? Strategic Management Journal, 26, 947-965. doi: 10.1002/smj.488. 
European Commission (1998). Risk capital: a key to job creation in the European Union, SEC(1998) 552, Brussels. Retrieved from: http://ec.europa.eu/economy_finance/publications/publication_summary1138_en.htm.

EVCA (2014). 2013 European Private Equity Activity: Statistics on Fundraising, Investments and Divestments. Retrieved from: http://www.evca.eu/media/142790/2013-EuropeanPrivate-Equity-Activity.pdf.

Ferrary, M. (2010). Syndication of Venture Capital Investment: The Art of Resource Pooling. Entrepreneurship Theory \& Practice, 34(5), 885-907. doi: 10.1111/j.15406520.2009.00356.x.

Fritsch, M., \& Schilder, D. (2008). Does venture capital investment really require spatial proximity? An empirical investigation. Environment and Planning, A 40, 2114-2131. doi: $10419 / 27101$.

Giot, P., \& Schwienbacher, A. (2007). IPOs, trade sales and liquidations: Modeling venture capital exits using survival analysis. Journal of Banking \& Finance, 31: 679-702. doi:10.1016/j.jbankfin.2006.06.010.

Gompers, P. A. (1995). Optimal investment, monitoring, and the staging of venture capital. Journal of Finance, 50, 1461-89. doi: 10.1111/j.1540-6261.1995.tb05185.x.

Gompers, P. A. (2002). Corporations and the financing of innovation: the corporate venturing experience. Federal Reserve Bank of Atlanta Economic Review Fourth Quarter, 1-16. Retrieved from: http://ssrn.com/abstract=1513133.

Green, J. (2004). Venture capital at a new crossroads: lessons from the Bubble. Journal of Management Development, 23, 972-976. doi: 10.1108/02621710410566883.

Grilli, L., \& Murtinu, S. (2014). Government, venture capital and the growth of European high-tech entrepreneurial firms. Research Policy, 43(9), 1523-1543. doi:10.1016/j.respol.2014.04.002.

Grilli, L., \& Murtinu, S. (2015). New technology-based firms in Europe: market penetration, public venture capital, and timing of investment. Industrial and Corporate Change, forthcoming. doi: 10.1093/icc/dtu025.

Grupp, H. (1994). The measurement of technical performance of innovations by technometrics and its impact on established technology indicators. Research Policy, 23, 175-193. doi: 10.1016/0048-7333(94)90052-3.

Gupta, A. K., \& Sapienza, H. J. (1992). Determinants of venture capital firms' preferences regarding the industry diversity and geographic scope of their investments. Journal of Business Venturing, 7, 347-362. doi: 10.1016/0883-9026(92)90012-G.

Hellmann, T. F., Lindsey, L., \& Puri, M. (2008). Building relationships early: banks in venture capital. Review of Financial Studies, 21, 513-541. doi: 10.1093/rfs/hhm080.

Ivanov, V. I., \& Xie, F. (2010). Do Corporate Venture Capitalists Add Value to Start-Up Firms? Evidence from IPOs and Acquisitions of VC-Backed Companies. Financial Management, 39(1), 129-152. doi:10.1111/j.1755-053X.2009.01068.x

Jeng, L. A., \& Wells, P. C. (2000). The determinants of venture capital funding: evidence across countries. Journal of Corporate Finance, 6(3), 241-289. doi: 10.1016/S09291199(00)00003-1.

Katila, R., Rosenberger, J. D., \& Eisenhardt, K. M. (2008). Swimming with sharks: technology ventures, defense mechanisms and corporate relationships. Administrative Science Quarterly, 53(2), 295-332. doi: 10.2189/asqu.53.2.295.

Lehmann, E. E. (2006). Does Venture Capital Syndication Spur Employment Growth and Shareholder Value? Evidence from German IPO Data. Small Business Economics, 26(6): 455-464. doi: 10.1007/s11187-005-5599-z 
Leleux, B., \& Surlemont, B. (2003). Public versus private venture capital: seeding or crowding out? A pan-European analysis. Journal of Business Venturing, 18, 81-104. doi: 10.1016/S0883-9026(01)00078-7.

Lerner, J. (1999). The Government as venture capitalist: the long-run impact of the SBIR Program. The Journal of Business, 72(3), 285-318. doi: 10.3905/jpe.2000.319960.

Lerner, J. (2002). When bureaucrats meet entrepreneurs: the design of effective "public venture capital" programmes. The Economic Journal, 112, F73-F84. doi: 10.1111/14680297.00684.

Levin, R. C., Klevorick, A. K., Nelson, R. R., Winter, S. G., Gilbert, R., \& Griliches Z. (1987). Appropriating the returns from industrial R\&D. Brookings Papers on Economic Activity, 3, 783-831.

Liechtenstein, H., Groh, A., Lieser, K. \& Biesinger, M. (2014) The Venture Capital \& Private Equity Country Attractiveness Index: 2014, IESE, ST-340-E, 05/2014.

Luukkonen, T., Deschryvere, M., \& Bertoni, F. (2013). The value added by government venture capital funds compared with independent venture capital funds. Technovation, 33(4-5): 154-162. doi: 10.1016/j.technovation.2012.11.007.

Malerba, F. (2004). Sectoral systems of innovation: basic concepts. In F. Malerba (Ed.). Sectoral systems of innovation: concepts, issues and analysis of six major sectors in Europe (pp. 9-41). Cambridge, MA: Cambridge University Press.

Mayer, C., Schoors, K., \& Yafeh, Y. (2005). Sources of funds and investment activities of venture capital funds: evidence from Germany, Israel, Japan and the United Kingdom. Journal of Corporate Finance, 11(3), 586-608. doi: 10.1016/j.jcorpfin.2004.02.003.

Montobbio, F. (2004). Sectoral dynamics and structural change: stylized facts and "system of innovation" approaches, In F. Malerba (Ed.). Sectoral systems of innovation: concepts, issues and analysis of six major sectors in Europe (pp. 42-69). Cambridge, MA: Cambridge University Press.

Murray, G. C. (1999). Early-stage venture capital funds, scale economies and public support. Venture Capital: An International Journal of Entrepreneurial Finance, 1(4), 351-384. doi:10.1080/136910699295857.

OECD (2013), Entrepreneurship at a Glance 2013, Ed. OECD. doi: 10.1787/entrepreneur_aag-2013-en.

Pavitt, K. L. R. (1988). International patterns of technological accumulation. In N. Hood \& J. E. Vahlne (Eds.). Strategies in Global Competition. Croom Helm, London.

Sahlman, W. A. (1990). The structure and governance of venture-capital organizations. Journal of Financial Economics, 27(2), 473-521. doi: 10.1016/0304-405X(90)90065-8.

Schertler, A., \& Tykvová, T. (2010). Venture capital and internationalization. International Business Review, 20, 423-439. doi: 10.2139/ssrn.1495717.

Schubert, T., \& Grupp, H. (2011). Tests and confidence intervals for a class of scientometric, technological and economic specialization ratios. Applied Economics, 43, 941-950. doi: $10.1080 / 00036840802600160$.

Schwienbacher, A. (2008). Venture Capital Investment Practices in Europe and in the United States. Financial Markets and Portfolio Management, 22 (3), 195-217. doi: 10.1007/s11408-008-0080-z.

Schwienbacher, A., Hege, U., \& Palomino, F. (2009). Venture Capital Performance: The Disparity between Europe and the United States. Finance, 30 (1), 7-50. ISBN: 9782706115660.

SITRA (2011), Annual Report 2010. Retrieved from: http://www.sitra.fi/julkaisut/Toimintakertomus/2010/Sitra_Boardreport2010.pdf. 
Soete, L. G., \& Sally, M. E. W. (1983). The use of foreign patenting as an internationally comparable science and technology output indicator. Scientometrics, 5(1), 31-54. doi: 10.1007/BF02097176.

Sorenson, O., \& Stuart, T. E. (2001). Syndication Networks and the Spatial Distribution of Venture Capital Investments. The American Journal of Sociology, 106(6), 1546-1588. doi:10.1086/321301

Vollrath, T. L. (1991). A theoretical evaluation of alternative trade intensity measures of revealed comparative advantage. Review of World Economics, 127, 265-280. doi: 10.1007/BF02707986. 


\section{Tables}

\section{Table 1: Distribution of the VC Investments}

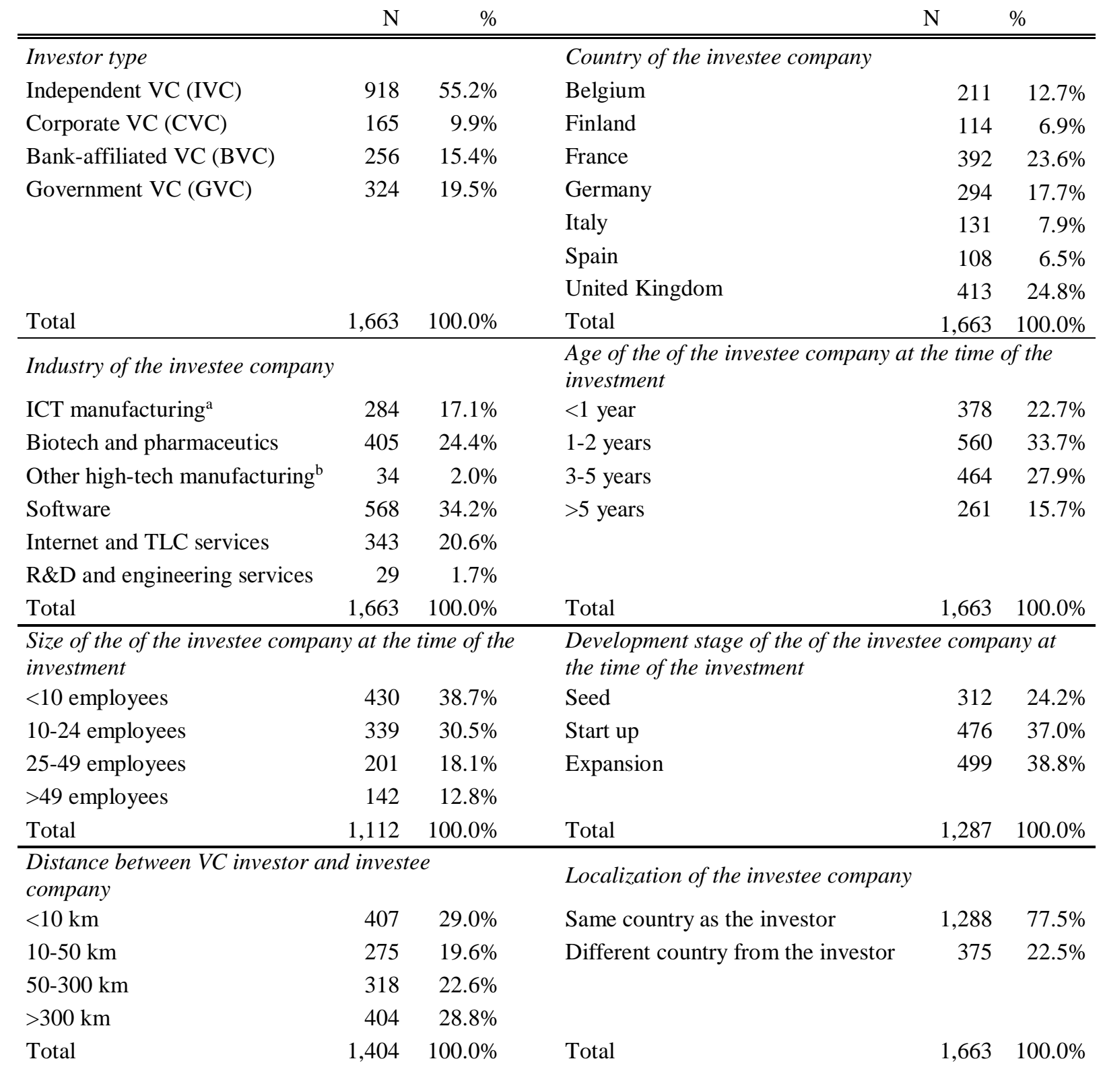

a This category includes electronic components, computers, telecommunication equipment, electronic, medical and optical instruments. ${ }^{\mathrm{b}}$ This category includes robotics and automation equipment, aerospace. 
Table 2: TBIs of Different Types of VC Investor in Europe

\begin{tabular}{|c|c|c|c|c|c|c|c|c|}
\hline \multirow{2}{*}{ Industry of the investee company } & \multicolumn{2}{|c|}{ IVC } & \multicolumn{2}{|c|}{$\mathrm{CVC}$} & \multicolumn{2}{|c|}{$\mathrm{BVC}$} & \multicolumn{2}{|c|}{ GVC } \\
\hline & & & & & & & & \\
\hline \multirow{2}{*}{ ICT manufacturing ${ }^{\mathrm{a}}$} & 0.019 & & -0.123 & & -0.020 & & 0.015 & \\
\hline & $(0.023)$ & & $(0.094)$ & & $(0.065)$ & & $(0.054)$ & \\
\hline \multirow[t]{2}{*}{ Biotech and pharmaceutics } & -0.013 & & -0.179 & $* *$ & 0.013 & & 0.093 & $* *$ \\
\hline & $(0.020)$ & & $(0.080)$ & & $(0.050)$ & & $(0.038)$ & \\
\hline \multirow[t]{2}{*}{ Other high-tech manufacturing ${ }^{b}$} & -0.182 & $*$ & 0.280 & $*$ & -0.447 & & 0.325 & $* * *$ \\
\hline & $(0.104)$ & & $(0.168)$ & & $(0.273)$ & & $(0.096)$ & \\
\hline \multirow[t]{2}{*}{ Software } & -0.014 & & 0.023 & & -0.003 & & 0.028 & \\
\hline & $(0.016)$ & & $(0.049)$ & & $(0.040)$ & & $(0.033)$ & \\
\hline \multirow[t]{2}{*}{ Internet and TLC services } & 0.052 & $* * *$ & 0.150 & $* * *$ & 0.029 & & -0.366 & $* * *$ \\
\hline & $(0.019)$ & & $(0.057)$ & & $(0.054)$ & & $(0.070)$ & \\
\hline \multirow[t]{2}{*}{ R\&D and engineering services } & -0.280 & $* *$ & 0.163 & & 0.057 & & 0.321 & $* * *$ \\
\hline & $(0.127)$ & & $(0.223)$ & & $(0.201)$ & & $(0.105)$ & \\
\hline \multicolumn{9}{|c|}{ Age of the investee company at the time of the investment } \\
\hline \multirow[t]{2}{*}{$<1$ year } & -0.042 & $*$ & 0.032 & & -0.197 & $* * *$ & 0.185 & $* * *$ \\
\hline & $(0.022)$ & & $(0.065)$ & & $(0.067)$ & & $(0.033)$ & \\
\hline \multirow[t]{2}{*}{$1-2$ years } & 0.001 & & 0.030 & & -0.007 & & -0.014 & \\
\hline & $(0.015)$ & & $(0.049)$ & & $(0.041)$ & & $(0.036)$ & \\
\hline \multirow[t]{2}{*}{$3-5$ years } & 0.046 & $* * *$ & -0.046 & & 0.050 & & -0.186 & $* * *$ \\
\hline & $(0.016)$ & & $(0.063)$ & & $(0.043)$ & & $(0.051)$ & \\
\hline \multirow[t]{2}{*}{$>5$ years } & -0.033 & & -0.038 & & 0.138 & $* *$ & -0.019 & \\
\hline & $(0.027)$ & & $(0.090)$ & & $(0.054)$ & & $(0.059)$ & \\
\hline \multicolumn{9}{|c|}{ Size of the investee company at the time of the investment } \\
\hline \multirow[t]{2}{*}{$<10$ employees } & -0.042 & $* *$ & 0.024 & & -0.151 & $* * *$ & 0.189 & $* * *$ \\
\hline & $(0.019)$ & & $(0.054)$ & & $(0.051)$ & & $(0.027)$ & \\
\hline \multirow[t]{2}{*}{ 10-24 employees } & 0.002 & & 0.058 & & 0.026 & & -0.068 & \\
\hline & $(0.021)$ & & $(0.062)$ & & $(0.047)$ & & $(0.053)$ & \\
\hline \multirow[t]{2}{*}{ 25-49 employees } & 0.046 & $*$ & -0.178 & & 0.068 & & -0.152 & $*$ \\
\hline & $(0.026)$ & & $(0.116)$ & & $(0.063)$ & & $(0.081)$ & \\
\hline \multirow[t]{2}{*}{ > 49 employees } & 0.048 & & -0.006 & & 0.187 & $* * *$ & -0.575 & $* * *$ \\
\hline & $(0.032)$ & & $(0.118)$ & & $(0.063)$ & & $(0.121)$ & \\
\hline \multicolumn{9}{|c|}{ Development stage of the investee company at the time of the investment } \\
\hline \multirow[t]{2}{*}{ Seed } & -0.051 & $* *$ & -0.062 & & -0.080 & & 0.180 & $* * *$ \\
\hline & $(0.024)$ & & $(0.086)$ & & $(0.067)$ & & $(0.036)$ & \\
\hline \multirow[t]{2}{*}{ Start up } & -0.008 & & -0.005 & & -0.015 & & 0.034 & \\
\hline & $(0.016)$ & & $(0.059)$ & & $(0.046)$ & & $(0.034)$ & \\
\hline \multirow[t]{2}{*}{ Expansion } & 0.037 & $* * *$ & 0.040 & & 0.057 & & -0.207 & $* * *$ \\
\hline & $(0.014)$ & & $(0.053)$ & & $(0.039)$ & & $(0.047)$ & \\
\hline
\end{tabular}


Table 2: (cont.)

IVC

Distance between investor and investee company

$<10 \mathrm{~km}$

$-0.053 * * *$

$(0.020)$

$-0.069 * *$

(0.027)

$0.063 * * *$

$(0.019)$

$0.040 * *$

$(0.017)$

$>300 \mathrm{~km}$

Localization of the investee company

Same country of the investor

Different country from the investor

(0.017)

CVC

BVC

GVC

$-0.143 *$
$(0.084)$

$-0.013$

$0.165 * * *$

$-0.035$

$(0.050)$

$(0.030)$

$0.181 * * * \quad 0.024$

(0.095)

(0.047)

$(0.051)$

$-0.107$

$-0.209 * * *$

$-0.016$

(0.094)

$(0.074)$

$(0.050)$

$0.184 * * *$

$-0.001$

$-0.255 * * *$

$(0.051)$

$(0.049)$

$(0.056)$

\begin{tabular}{|c|c|c|c|c|c|}
\hline-0.009 & -0.127 & $* * *$ & -0.001 & 0.077 & $* * *$ \\
\hline (0.006) & $(0.029)$ & & $(0.016)$ & $(0.009)$ & \\
\hline 0.030 & 0.279 & $* * *$ & 0.002 & -0.404 & $* * *$ \\
\hline$(0.019)$ & $(0.041)$ & & $(0.053)$ & $(0.068)$ & \\
\hline
\end{tabular}

Legend. For each investment dimension, the table shows the TBI of each investor in each investment category. Standard deviations are in parentheses. It also shows the significance of $t$-tests of the null hypothesis that the TBI be equal to 0. ${ }^{*} \mathrm{p}<10 \% ; * * \mathrm{p}<5 \% ; * * * \mathrm{p}<1 \%$. ${ }^{a}$ Electronic components, computers, telecommunication equipment, electronic, medical and optical instruments. ${ }^{\mathrm{b}}$ Robotics and automation equipment, aerospace. 
Table 3: Spearman's Correlation of the TBIs of Different Types of VC Investor in Europe

\begin{tabular}{lrrrr} 
& IVC & CVC & BVC & GVC \\
\hline \hline IVC & 1 & & & \\
CVC & -0.065 & 1 & 1 & \\
BVC & 0.237 & -0.060 & -0.115 & $-0.564 * * *$ \\
GVC & $-0.843 * * *$ & $* * *$ & 1 \\
\hline \hline
\end{tabular}

Legend. ${ }^{*} \mathrm{p}<10 \% ; * * \mathrm{p}<5 \% ; * * * \mathrm{p}<1 \%$. Number of observations: 23 .

Table 4. Spearman's Correlation of the TBIs of Different Types of VC Investor in Europe Before and After the Internet Bubble

\begin{tabular}{lcc} 
VC investor type & Number of observations & Spearman \\
\hline \hline All & 92 & $0.53 * * *$ \\
IVC & 23 & $0.65 * * *$ \\
CVC & 23 & 0.24 \\
BVC & 23 & $0.38 *$ \\
GVC & 23 & $0.81 * * *$ \\
\hline \hline
\end{tabular}

Legend. *p<10\%; **p<5\%; ***p<1\%. 
Table 5. Spearman's Correlation of the TBIs of Different Types of VC Investor in each country and in the rest of the sample

Number of observations

Spearman

\begin{tabular}{lll}
\hline \hline All & 604 & $0.32 * * *$ \\
By country & & \\
Belgium vs. rest of sample & 88 & $0.51 * * *$ \\
Finland vs. rest of sample & 88 & $0.32 * * *$ \\
France vs. rest of sample & 88 & $0.37 * * *$ \\
Germany vs. rest of sample & 88 & $0.23 * *$ \\
Italy vs. rest of sample & 76 & $0.25 * *$ \\
Spain vs. rest of sample & 88 & $0.23 * *$ \\
United Kingdom vs. rest of sample & 88 & $0.32 * * *$ \\
By VC investor type & & \\
IVC & 151 & $0.21 * * *$ \\
CVC & 151 & $0.14 *$ \\
BVC & 151 & $0.23 * * *$ \\
GVC & 151 & $0.59 * * *$ \\
\hline \hline
\end{tabular}

Legend. ${ }^{*} \mathrm{p}<10 \% ; * * \mathrm{p}<5 \% ; * * * \mathrm{p}<1 \%$. In this table the industry dimension has been reclassified in 5 categories instead of 6. 
Table 6: Distribution of the VC Investments by Types of VC Investor and

Characteristics of Investee Companies in the US (1994-2004)

\begin{tabular}{|c|c|c|c|c|c|}
\hline & $\mathrm{N}$ & $\%$ & & $\mathrm{~N}$ & $\%$ \\
\hline \multicolumn{6}{|l|}{$V C$ investor type } \\
\hline Independent VC (IVC) & 16,478 & $68.0 \%$ & & & \\
\hline Corporate VC (CVC) & 4,207 & $17.4 \%$ & & & \\
\hline Bank affiliated VC (BVC) & 2,955 & $12.2 \%$ & & & \\
\hline Government VC (GVC) & 602 & $2.5 \%$ & & & \\
\hline Total & 24,242 & $100.0 \%$ & & & \\
\hline \multicolumn{3}{|l|}{ Industry of the investee company } & \multicolumn{3}{|c|}{ Age of the investee company at the time of the investment } \\
\hline ICT manufacturing & 3,751 & $15.5 \%$ & $<1$ year & 5,646 & $23.5 \%$ \\
\hline Biotech and pharmaceutics & 2,283 & $9.4 \%$ & $1-2$ years & 9,601 & $40.0 \%$ \\
\hline Other high-tech manufacturing & 311 & $1.3 \%$ & 3-5 years & 6,447 & $26.9 \%$ \\
\hline Software & 9,243 & $38.1 \%$ & $>5$ years & 2,282 & $9.5 \%$ \\
\hline Internet and TLC services & 7,428 & $30.6 \%$ & & & \\
\hline$R \& D$ and engineering services & 1,226 & $5.1 \%$ & & & \\
\hline Total & 24,242 & $100.0 \%$ & Total & 23,976 & $100.0 \%$ \\
\hline
\end{tabular}

Source: Thomson One. 
Table 7: TBIs of Different Types of VC Investors in the US

\section{Industry of the investee company}

\begin{tabular}{|c|c|c|c|c|c|c|c|c|}
\hline ICT manufacturing & $\begin{array}{l}-0.002 \\
(0.005)\end{array}$ & & $\begin{array}{l}0.041 \\
(0.015)\end{array}$ & $* * *$ & $\begin{array}{l}-0.041 \\
(0.021)\end{array}$ & $*$ & $\begin{array}{l}-0.034 \\
(0.049)\end{array}$ & \\
\hline Biotech and pharmaceutics & $\begin{array}{l}-0.015 \\
(0.007)\end{array}$ & $* *$ & $\begin{array}{l}-0.063 \\
(0.023)\end{array}$ & $* * *$ & $\begin{array}{l}0.082 \\
(0.024)\end{array}$ & $* * *$ & $\begin{array}{l}0.276 \\
(0.041)\end{array}$ & $* * *$ \\
\hline Other high-tech manufacturing & $\begin{array}{l}-0.011 \\
(0.020)\end{array}$ & & $\begin{array}{l}-0.125 \\
(0.070)\end{array}$ & $*$ & $\begin{array}{l}0.138 \\
(0.063)\end{array}$ & $* *$ & $\begin{array}{l}0.217 \\
(0.134)\end{array}$ & \\
\hline Software & $\begin{array}{l}0.006 \\
(0.003)\end{array}$ & $* *$ & $\begin{array}{l}-0.009 \\
(0.009)\end{array}$ & & $\begin{array}{l}-0.011 \\
(0.011)\end{array}$ & & $\begin{array}{l}-0.047 \\
(0.028)\end{array}$ & $*$ \\
\hline Internet and TLC services & $\begin{array}{l}-0.002 \\
(0.003)\end{array}$ & & $\begin{array}{l}0.019 \\
(0.010)\end{array}$ & $*$ & $\begin{array}{l}-0.001 \\
(0.013)\end{array}$ & & $\begin{array}{l}-0.077 \\
(0.034)\end{array}$ & $* *$ \\
\hline $\mathrm{R} \& \mathrm{D}$ and engineering services & $\begin{array}{l}0.008 \\
(0.009) \\
\end{array}$ & & $\begin{array}{l}-0.046 \\
(0.032) \\
\end{array}$ & & $\begin{array}{l}0.002 \\
(0.037) \\
\end{array}$ & & $\begin{array}{l}0.084 \\
(0.079) \\
\end{array}$ & \\
\hline \multicolumn{9}{|c|}{ Age of the investee company at the time of the investment } \\
\hline$<1$ year & $\begin{array}{l}0.052 \\
(0.003)\end{array}$ & $* * *$ & $\begin{array}{l}-0.143 \\
(0.015)\end{array}$ & $* * *$ & $\begin{array}{l}-0.141 \\
(0.018)\end{array}$ & $* * *$ & $\begin{array}{l}-0.016 \\
(0.039)\end{array}$ & \\
\hline $1-2$ years & $\begin{array}{l}-0.014 \\
(0.003)\end{array}$ & $* * *$ & $\begin{array}{l}0.036 \\
(0.008)\end{array}$ & $* * *$ & $\begin{array}{l}0.031 \\
(0.010)\end{array}$ & $* * *$ & $\begin{array}{l}-0.043 \\
(0.028)\end{array}$ & \\
\hline $3-5$ years & $\begin{array}{l}-0.027 \\
(0.004)\end{array}$ & $* * *$ & $\begin{array}{l}0.054 \\
(0.011)\end{array}$ & $* * *$ & $\begin{array}{l}0.043 \\
(0.013)\end{array}$ & $* * *$ & $\begin{array}{l}0.085 \\
(0.031)\end{array}$ & $* * *$ \\
\hline$>5$ years & $\begin{array}{l}-0.004 \\
(0.007)\end{array}$ & & $\begin{array}{l}-0.009 \\
(0.022)\end{array}$ & & $\begin{array}{l}0.042 \\
(0.025)\end{array}$ & $*$ & $\begin{array}{l}-0.054 \\
(0.070)\end{array}$ & \\
\hline
\end{tabular}

Legend. For each investment dimension, the table shows the TBI of each investor in each investment category. Standard deviations are in parentheses. It also shows the significance of t-tests of the null hypothesis that the TBI be equal to 0. ${ }^{*} \mathrm{p}<10 \% ; * * \mathrm{p}<5 \% ; * * * \mathrm{p}<1 \%$. Details on the industry reclassification are available from the authors upon request. 